\title{
High Pollution with Heavy Metals NATURA 2000 Protected Area in Bacau County, Eastern Romania
}

\author{
BOGDAN-IOAN BONTAS ${ }^{1}$, DIANA-CARMEN MIRILA ${ }^{2 *}$, GABRIEL GRITCU ${ }^{3}$, \\ ILEANA-DENISA NISTOR ${ }^{2 *}$, DOREL URECHE ${ }^{2}$ \\ ${ }^{1}$ Charles University in Prague, Faculty of Science \\ 2 "Vasile Alecsandri" University of Bacau, Faculty of Engineering, 157 Calea Marasesti, 600115, Bacau, Romania \\ 3 "Al. I. Cuza" University of Iasi, Faculty of Biology, 11 Carol I Blvd., 700506, Iasi, Romania
}

\begin{abstract}
Chemical pollution in rivers ecosystems is leading towards an increase in the concentrations of heavy metals in fish body, which might have a negative impact on humans. The fish were collected from a protected Natura 2000 area in the Moldavia region, eastern Romania named "Buhusi-BacauBeresti" Storage basin. The aim of this study was to measure the heavy metal concentrations in water, sediment and fish meat (muscles and gills), in order to assess the human health risk due to consumption. Industrial effluents discharged into the environment pose a serious threat for the agricultural products and living organisms. In view of this, level of some heavy metals, such as: $C d$, $\mathrm{Zn}, \mathrm{Pb}$ and $\mathrm{Cu}$ present in water, sediment and fish tissue samples of fish populations from the area studied were determined using wet digestion-based atomic adsorption method. This study revealed that the maximum Cd concentration $(0.911 \mathrm{mg} / \mathrm{Kg})$ was found in fish gills of specie European Perch Perca fluviatilis and the minimum $(0.0197 \mathrm{mg} / \mathrm{Kg})$ was found in Zander - Sander lucioperca fish muscle sample. Zn levels in fish gills of the studied samples were ranged from $108.6698 \mathrm{mg} / \mathrm{Kg}$ to $195.4167 \mathrm{mg} / \mathrm{Kg}$. Maximum Pb concentration in gills $(1.924 \mathrm{mg} / \mathrm{Kg})$ was found in fish sample of Zarte - Vimba vimba, while the minimum concentration $(0.45 \mathrm{mg} / \mathrm{Kg})$ was found in European Perch - Perca fluviatilis. The heavy metal found in the samples analyzed in the largest quantity is $\mathrm{Cu}$, in the gills of Northernpike - Esox Lucius fish.The concentration determined in samples exceeded the World Health Organisation maximum allowances. In order to assess the risk to which humans are exposed by eating infected meat with heavy metals, the target hazard quotient (THQ) values were estimated.
\end{abstract}

Keywords: heavy metals; fish fauna; biomarkers; pollutants; health risk

\section{Introduction}

Environmental pollution represents a serious problem due to the rapid increases of industrialization, fast development of economics, population growth and agricultural activities. Freshwater fishes are to be considered as great part of food potential for human population, because of exceptional type of protein, minerals, vitamins and having valuable lipids and fatty acids. A healthy and balanced diet should include at least 2 portions (a portion is around $140 \mathrm{~g}$ when is cooked) of fish a week, including 1 of oily fish (egg. herring, salmon, sardines, sports, trout, mackerel etc). Heavy metals and also other hazardous factors can be accumulated into such medium where these fishes are found [1]. It is already known that polluted fishes could be dangerous dietary sources for such toxic components or heavy metals $[2,3]$. Heavy metals are among the most persistent of pollutants in the ecosystem such as water, sediments and biota [4]. A heavy metal is a member of a loosely-defined subset of elements that present metallic properties. It mainly includes the transition metals, some metalloids, actinides and lanthanides. Different definitions have been proposed for those metals, some based on density, atomic number or atomic weight and on chemical properties or toxicity. They are very resistant to decomposition in natural conditions [5], hence there is a need to develop different remediation technique, which should be efficient, economical and rapidly deployable in a wide range of physical settings, and because have a low solubility in water and get adsorbed and accumulated on

*email:miriladiana@ub.ro;dnistor@ub.ro 
bottom sediments, acting as sink. Heavy metals contamination has been recognized as a major environmental problem due to their pervasiveness and persistence. The bio-accumulation of $\mathrm{Pb}, \mathrm{Cu}$, $\mathrm{Cd}$ and $\mathrm{Zn}$ in living organisms and bio-magnifications describes the processes and pathways of pollutants from one trophic level to another. Fish are widely used as bio-indicators of certain heavy metals contamination in aqua culture [6]. Bioaccumulation and bio-amplification of chemicals through the food chain may be a necessary condition for highlighting adverse effects in species and individuals. The redox potential, along with $p \mathrm{H}$, various organic compounds, humic substrate, complex particles, the presence or absence of other metals, anions, various ionic bonds, temperature, salinity, light intensity, dissolved oxygen plays an important role in the bioaccumulation of heavy metals [7]. At a low redox potential, the metals bind to the sulphides in the sediment becoming immobile. Sediments in rivers play an important role in influencing the pollution of river water and can be used to record the history of river pollution. The measurement of those in sediments is useful in order to collect information on the genesis of the level of sediment contamination [5]. Metals in aquatic environments originate from two natural sources, such as: 1). Weathering of soil and rock, erosion, forest fires, volcanic eruptions and 2). Anthropogenic activities. Heavy metals like: $\mathrm{Pb}, \mathrm{Cu}, \mathrm{Cd}$ and $\mathrm{Zn}$ in trace levels may not harm the organisms due to their biochemical role in the life processes of all fish and is considered to be essential metals in the aquatic and terrestrial environment [8]. Due to contamination of heavy metals in water and sediment cause serious threats to food chain, mostly fishes which can accumulate and biomagnifying the heavy metals [9, 10], because fish are the most significant biomonitors in aquatic systems for the estimation of metal pollution level [11]. It is already reported in the literature that pollutants circulate on different paths in ecosystems, either accumulate in the body of vegetal and animal organisms, or concentrate in a food chain [12]. The relationship between the ecosystem pollution level and the bioconcentration of the trophic elements is even more important at the level of the Natura 2000 site "Buhusi - Bacău - Bereşti" reservoirs, as here are encountered well formed and interdependent trophic networks. Much of the birds protected at the site level are ihtiofage species, this category including about 28 taxa. Their feeding regime is exclusively related to the aquatic environment, so any willful or accidental disturbance of this environment will lead to direct changes in the dynamics of this category. However, the largest category of birds is represented by invertebrate consumers, which add up to a total of 89 species. They are also not protected from the pollutants harmful to soil and water, their food being mainly composed of soft-bodied invertebrates, organisms with a rather high capacity of bioaccumulation of pollutants [13]. The objective of this paper is the realization of a study regarding the health of the fish population from a protected natural area (Natura 2000 site, ROSPA code 0063) from the region of Moldavia, Romania. The site was declared aifaunistic special protection area, by Government Decision no. 1284/2007 regarding the declaration of the special protection areas of avifauna as an integral part of the Natura 2000 European ecological network in Romania, published in OJ no. 739 bis of 31.10.2007. Natura 2000 is the central element of European Union biodiversity policies. It is a European network of protected natural areas established in accordance with the Habitats Directive of 1992. The aim of the network is to ensure the long-term survival of the most valuable and threatened species and habitats in Europe. Natura 2000 is made up of Special Areas of Conservation (AAC) designated by Member States under the Habitats Directive and also includes Special Protection Areas (SPAs), which they designate under the Birds Directive of 1979 [14]. Natura 2000 applies to the Birds Directive and the Habitats Directive, which are divided into biogeographically regions. This principle also applies to the marine environment. The Birds Directive provides for the establishment of Special Protection Areas (APSAs) - a specific category of protected natural areas - in major wintering areas, on migration corridors, in nesting places, and where endangered, rare and vulnerable bird species. Natura 2000 site, the accumulation reservoirs "Buhuşi - Bacau - Bereşti" ROSPA 0063 was established by the Government Decision no.1284 / 2007, published in OJ no. 739 bis of 31.10.2007 on the declaration of special aifaunistic protection areas (APSA) as an integral part of the European ecological network Natura 2000 in Romania. It was analysed the existence of heavy metals in the fishes that populate the lakes of this protected area with a 
view to ensuring the protection of the environment and of people's health. In the previous research, the extent of the contamination with potential toxic elements (heavy metals) of water and sediments from the Natura 2000 site has been evaluated. Concentrations of heavy metals for analysis of water and sediment samples highlighted water and sediment quality, with emphasis of certain exceedances of maximum legal values [15]. In this context, there is a need to control the degree of bioaccumulation of heavy metals in fish destined for human consumption, which has been the main objective of the present paper.

\section{Materials and methods}

\subsection{Description of study area}

Bacau-Buhusi-Beresti Storage Basin is located in the region of Moldova, Romania (Latitudes 27.128986; Longitudes 46.245383). The analysed area comprises an area of 5,575.5 hectares from which $83 \%$ are represented by rivers and lakes, $13 \%$ by marshes and peat bogs, $2 \%$ different crops and 2\% pastures (Annex. 2 of Government Decision no. 1284/2007).

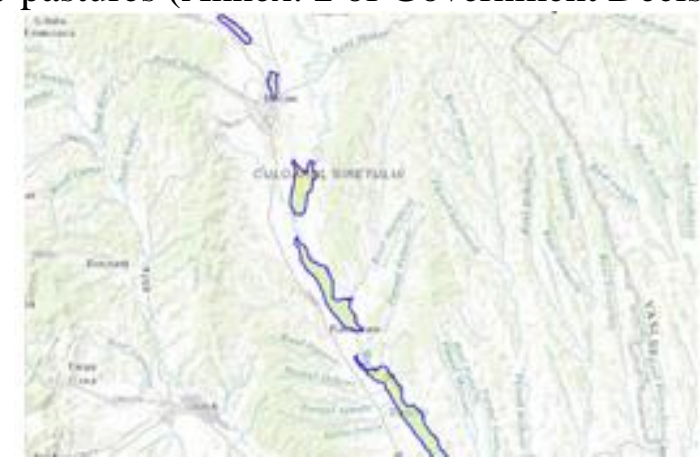

Figure. 1. Buhuşi -

Bacău - Bereşti Storage basin

The site hosts 5 special avifaunistic protection areas of national importance presented in Figure 1., as follows: Lake Lilieci 262 ha; Lake Bacău II 202 ha; Lake Galbeni 1132 ha; Lake Răcăciuni 2004 ha; Lake Bereşti 1800 ha. On the entire surface of the lake we can encounter different categories of birds with a special importance for the biodiversity of the space of the European community. In their large majority they are represented by transitory birds (47\%) followed by summer guests in a proportion amounting to $36 \%$ and winter guests in a smaller number of 12 . Moreover, the site houses important concentrations of endangered species [16] at the level of the European Union, such as Cygnus Cygnus (whooper swan), Sterna hirundo (common tern) and Circus aeruginosus (Western marsh herrier). Apart from these populations of birds, the site is also house to a rich ichthyofauna.

In 2018, from the 5 storage lakes comprised on the surface of the site, as well from the rivers which supply them with water, the fishing associations activate on the site fished a quantity of over 3 tonnes of fish used in one form or another in economy, of the following species: Cyprinus carpio, Abramis brama, Carassius gibelio, Rutilus rutilus, Chondrostoma nasus, Vimba vimba, Squalius cephalus, Silurus glanis, Sander lucioperca, Aspius aspius, Essox lucius, Perca fluviatilis. Fish is an important source of protein and nutrients for the human diet and currently fresh fish is the most sought after fishery and aquaculture product [17]. In this respect, two commercial fisheries associations are operating on the site: APC Europesca and APC Euro-Sas, as well as sports fishermen associations, the Regional Ecology Center Bacau and AJVPS Bacau, associations registering a total of about 3500 registered fishermen. Taking into consideration that the site represents an important source of food for the local communities from its perimeter and vicinity as well as for a fairly numerous population of aquatic birds it is important that a correlation should be achieved between the anthropic activities and their impact upon the fauna in this area. Samples of water for characterization of heavy metal concentrations were obtained from three stations designated along stretch of "Buhuşi - Bacău Bereşti" Storage basin at Bacau. The collection stations were numbered from 1 to 39, beginning with the northern limit of the site (Lake Lilieci) and ending with the dam area of Lake Bereşti. In Table 1 are presented all 39 collection stations, their GPS coordinates. 
Table 1. Description of the collection stations

\begin{tabular}{|c|c|c|c|}
\hline \multirow{2}{*}{$\begin{array}{l}\text { Collection } \\
\text { stations }\end{array}$} & \multicolumn{2}{|c|}{ GPS Coordinates } & \multirow[t]{2}{*}{ Description of the collection stations } \\
\hline & Latitude & Longitude & \\
\hline Point 1 & 46.651282 & 26.860782 & $\begin{array}{c}\text { Bistrita river course, Lake Lilieci, the point of } \\
\text { shedding Bistrita in the lake, the northern limit of } \\
\text { the site. }\end{array}$ \\
\hline Point 2 & 46.647099 & 26.862327 & $\begin{array}{l}\text { Bistrita river course, Lilieci Lake, the UGH Gârleni } \\
\text { canal spill area in Lilieci Lake. }\end{array}$ \\
\hline Point 3 & 46.639321 & 26.875888 & $\begin{array}{l}\text { Bistrita river course, Lilieci Lake, middle of the } \\
\text { lake. }\end{array}$ \\
\hline Point 4 & 46.631483 & 26.885501 & Bistrita river course, Lake Lilieci, dam area. \\
\hline Point 5 & 46.620696 & 26.905500 & Bistrita river course, Gheraiesti railway bridge. \\
\hline Point 6 & 46.612973 & 26.917259 & Bistrita river course, ovine sheepfold area. \\
\hline Point 7 & 46.595695 & 26.919319 & $\begin{array}{c}\text { Bistrita river course, Bacău lake, the point of shedding } \\
\text { Bistrita in the lake. }\end{array}$ \\
\hline Point 8 & 46.594515 & 26.915799 & $\begin{array}{c}\text { Bistrita river course, Bacău lake, the spill area of } \\
\text { Hidroelectrica } 1 \text { in the lake. }\end{array}$ \\
\hline Point 9 & 46.583190 & 26.922580 & Bistrita river course, Lake Bacau, middle lake. \\
\hline Point 10 & 46.575167 & 26.922151 & Bistrita river course, Bacău lake, dam area. \\
\hline Point 11 & 46.572660 & 26.923896 & $\begin{array}{l}\text { Bistrita river course, Bacău recreation lake, Bârnat } \\
\text { river spill area in Bacău Recreation Lake. }\end{array}$ \\
\hline Point 12 & 46.564486 & 26.927582 & $\begin{array}{c}\text { Bistrita river course, Bacău recreation lake, middle } \\
\text { of the lake. }\end{array}$ \\
\hline Point 13 & 46.557788 & 26.927668 & $\begin{array}{c}\text { Bistrita river course, Bacau Recreation Lake, dam } \\
\text { lake area. }\end{array}$ \\
\hline Point 14 & 46.556361 & 26.929128 & Course of Bistrita River, TCH spill area. \\
\hline Point 15 & 46.530174 & 26.942904 & Course of Bistrita River, CRAB discharge area. \\
\hline Point 16 & 46.507746 & 26.952850 & Bistrita river course, spill area SC Amurco SRL. \\
\hline Point 17 & 46.509990 & 26.976539 & $\begin{array}{l}\text { The Bistrita River course, the UHE Bacău } 2 \text { channel } \\
\text { spill area in Lake Galbeni. }\end{array}$ \\
\hline Point 18 & 46.505517 & 26.980047 & $\begin{array}{l}\text { Bistrita river course, Bistrita river confluence area } \\
\text { with the Siret river. }\end{array}$ \\
\hline Point 19 & 46.492306 & 26.975918 & $\begin{array}{c}\text { Siret river course, Lake Galbeni, Tamaş station } \\
\text { discharge area. }\end{array}$ \\
\hline Point 20 & 46.499584 & 26.959218 & $\begin{array}{c}\text { Course of Siret River, Lake Galbeni, Sortbac Salt } \\
\text { Lake Area. }\end{array}$ \\
\hline Point 21 & 46.481857 & 26.952523 & $\begin{array}{c}\text { Course of the Siret River, Lake Galbeni, the tail of } \\
\text { the lake. }\end{array}$ \\
\hline Point 22 & 46.471336 & 26.963767 & $\begin{array}{l}\text { Siret river course, lake Galbeni, flooded area in the } \\
\text { lake bed. }\end{array}$ \\
\hline Point 23 & 46.455727 & 26.955871 & Course of Siret River, Lake Galbeni, dam area. \\
\hline Point 24 & 46.438779 & 26.952795 & Course of Siret River. \\
\hline Point 25 & 46.420380 & 26.960005 & $\begin{array}{l}\text { The Siret River course, the Siret confluence area } \\
\text { with the Cleja brook. }\end{array}$ \\
\hline Point 26 & 46.406829 & 26.976913 & $\begin{array}{l}\text { Course of Siret River, Lake Răcăciuni, the spill } \\
\text { area of the Hidroelectrica Galbeni plant in Lake } \\
\text { Răcăciuni. }\end{array}$ \\
\hline Point 27 & 46.365977 & 27.007898 & $\begin{array}{l}\text { Course of the Siret River, Lake Răcăciuni, middle } \\
\text { of the lake. }\end{array}$ \\
\hline Point 28 & 46.366012 & 27.033390 & $\begin{array}{c}\text { Course of the Siret River, Lake Răcăciuni, the area } \\
\text { of the Ratău Stream in the lake. }\end{array}$ \\
\hline Point 29 & 46.348419 & 27.035450 & $\begin{array}{c}\text { Course of the Siret River, Lake Răcăciuni, middle } \\
\text { of the lake. }\end{array}$ \\
\hline Point 30 & 46.334850 & 27.048324 & $\begin{array}{l}\text { Course of Siret River, Lake Răcăciuni, dam lake } \\
\text { area. }\end{array}$ \\
\hline Point 31 & 46.323903 & 27.048360 & Course of Siret River. \\
\hline Point 32 & 46.296200 & 27.062827 & $\begin{array}{c}\text { Course of the Siret River, the confluence of the } \\
\text { Drăguşani brook with the Siret River. }\end{array}$ \\
\hline Point 33 & 46.284575 & 27.098790 & $\begin{array}{l}\text { Course of the Siret River, Lake Bereşti, the UHE } \\
\text { Splashing Zone of Răcăciuni in Lake Bereşti. }\end{array}$ \\
\hline Point 34 & 46.271900 & 27.100335 & Course of Siret River, Lake Bereşti, reed area. \\
\hline
\end{tabular}




\begin{tabular}{|c|c|c|c|}
\hline Point 35 & 46.259912 & 27.105926 & $\begin{array}{l}\text { Course of Siret River, Lake Bereşti, sheep flock } \\
\text { area. }\end{array}$ \\
\hline Point 36 & 46.247446 & 27.143401 & $\begin{array}{c}\text { Course of the Siret River, Lake Bereşti, the spill area of } \\
\text { the Rogoaza brook in the lake. }\end{array}$ \\
\hline Point 37 & 46.230244 & 27.142662 & $\begin{array}{l}\text { Course of the Siret River, Lake Bereşti, middle of } \\
\text { the lake. }\end{array}$ \\
\hline Point 38 & 46.209815 & 27.173990 & $\begin{array}{c}\text { Course of Siret River, Bereşti Lake, Corinii de Sus } \\
\text { area. }\end{array}$ \\
\hline Point 39 & 46.186289 & 27.185406 & $\begin{array}{l}\text { Course of the Siret River, Lake Bereşti, dam lake } \\
\text { area. }\end{array}$ \\
\hline
\end{tabular}

\subsection{Anthropic activities impacting on habitats in the sites perimeter}

According to the management plan, there are 18 localities, with a total of 267,667 inhabitants, within the Natura 2000 "Buhusi - Bacau - Beresti" accumulation reservoirs. They carry out the following categories of activities, some of which are deleterious to the environment: agricultural and forestry activities; fishing, hunting, harvesting; mining and extraction of minerals; urbanization and industrialization activities; transport and communications; tourism; and hydro technical arrangements. Despite the fact that environmentally friendly industrial means are being used in the last decade, the following activities have contributed to the release of heavy metals in the environment (according to ARM Bacau data) have taken place within Bacau: transport road, involving the combustion of petrol and diesel fuel; coal burning - lignite; combustion in the energy industry and transformation industries; non-industrial combustion installations; combustion in the processing industry; waste treatment and storage; other mobile sources and equipment. According to the reports prepared by APM Bacau, in 2018, there were 144 environmental, accidental or accidental environmental events, resulting in the discharge of various pollutants into the environment (air, water, soil), within the county of Bacau. The main events are characterized by the release of ammonia into the air, the spreading of petroleum products, oil and water mixtures on the soil and in the water, the spreading of slag powders into the air, the spillage of liquid fuels, the spillage of manure in watercourses, unknown pollutants on soils or water, and various events that have led to fish mortality.

\subsection{Field sampling}

The sampling duration was from 1 October 2018 to 1 July 2019. Water, sediment and fish samples were collected in the early hours of the every weekend morning (Sunday and Saturday) between 5 am and $10 \mathrm{am}$ at the sampling stations. Water and sediment samples for heavy metal determination were collected and stored in acid washed polyethylene bottles and glass jars, placed in a cooler at $4^{\circ} \mathrm{C}$ and transported to the laboratory immediately for further analysis. For water and sediment analysis: $1 \mathrm{~L}$ of water respectively $1 \mathrm{Kg}$ of sediment were collected from each of the 39 collection points, mentioned in Table 1.

\subsection{Health risk}

This study was conducted by comparing the recommended daily dose with the heavy metal concentrations found in fish, as well as the target risk coefficient equation [18]. Health human risk was estimated considering the average concentrations found in all fish muscles and gills and daily heavy metal intake (EDI), through equation (1) [19].

$$
E D I=\frac{C x F C x E_{f} x E_{d}}{B_{W} x A_{t}} x 10^{-3}
$$

where: $\mathrm{C}$ is the average concentration of heavy metals in fish muscles and gills $(\mathrm{mg} / \mathrm{Kg}$ dry weight); $\mathrm{FC}$ is the rate of fish consumption (49.5g/day/person); Ed represent the exposure duration, around 70 years as average lifetime [20]; Ef is the exposure frequency (365 days/year); Bw is the average adult body weight $(60-70 \mathrm{Kg}$ ); At represent the average exposure time for non-carcinogens (might be 70 years). 
The method of estimating the target hazard quotient (THQ) provides allot of indication about the human health risk by the exposure of the body to these heavy metals. The risks for ingestion of the pollutants were assessed based on target hazard quotients (THQs) through the Eq. (2) [19]. The THQs value must be less than 1 , and in this way the toxic effect are not expected to occur[19]. In the case of higher than 1 there exist a real risk on health and need interventions and protective measurements in order to protect the humans health[18].

$$
T H Q=\frac{C x F C x E_{f} x E_{d}}{B_{W} x A_{t} x R_{d}} \times 10^{-3}
$$

By evaluating the health risk to local people in the area of the storage posed by the consumption of fish, the data from the fish muscles and gills samples were used for a risk assessment. The daily in-take of pollutants was estimated on the basis of the concentration of heavy metals in the fish samples. The THQ values were calculated based on the following oral reference doses (Rds) i.e. 1.7, 0.06, 5× 10-2 and $0.006 \mathrm{mg} / \mathrm{Kg} /$ day for $\mathrm{Cd}, \mathrm{Cu}, \mathrm{Zn}$ and $\mathrm{Pb}$ respectively [21, 22].

\subsection{Chemical analysis reagents and standards}

All reagents were of analytical grade and purchased from Merck, double deionized water was used for the preparation of all solutions. The element standard solutions used for calibration were pre-pared by diluting stock solutions of $2000 \mathrm{mg} / \mathrm{L}$ of each element. Stock standard solutions were Merck Certificate AA standard. All glass vessels used were cleaned by soaking in dilute acid for at least $48 \mathrm{~h}$ and rinsed in deionized water before use. Water, sediment and biological tissue samples were taken.

Tests were carried out to determine the content of heavy metals from 1.) water in which fish live; 2.) sediment from that water and 3.) from the fish meat (respectively from gills and muscles), collected and fished from the 39 collection stations.

\subsection{Analysis of water and sediment samples}

Collection and storage of water and sediment samples was done in sterile containers kept for 24-48 $\mathrm{h}$ at $4^{\circ} \mathrm{C}$. Sediment samples were air dried and the sieved sample was powdered and finally passed through a $250 \mu \mathrm{m}$ sieve, and stored in a glass vessel. For heavy metal content determinations, $1 \mathrm{~g}$ sediment subsamples were digested in teflon vessels with $20 \mathrm{~mL} \mathrm{HNO}_{3}$ : $\mathrm{HCl}(2: 1)$ mixture in a microwave oven (Whirlpool AMW 730/NB, $1000 \mathrm{~W}$ ). After microwave digestion, the samples were filtered and adjusted to a suitable volume with double deionized water. The water and sediment samples were analysed through atomic (Analytical Methods for Atomic Absorption Spectroscopy, Srikanth P, 2017) and flame using the Perkin-Elmer spectrophotometer with atomic adsorption, model Analyst 700.

\subsection{Analysis of fish samples}

All samples from the fish captured in weekend were refrigerated at $4^{\circ} \mathrm{C}$ and analyzed the following week Monday. On Monday, when all the samples collected from the previous weekend arrived at the laboratory, the species was identified, these being presented in the Table 4. The fish were eviscerated using ceramic tools, taking the dorsal muscles of the fish as well as their gills for analysis. The fish samples were dried in the Whirlpool AMW 730/NB, $1000 \mathrm{~W}$ oven for $1 \mathrm{~h}$ at $55^{\circ} \mathrm{C}$, milled to homogeneity with ceramic mortar and pestle, and digested using a MARS 6 - Microwave Digestion System. For the analysis were used $1 \mathrm{~g}$ of fish sample digested using a mixture of $15 \mathrm{~mL}$ of $65 \%$ nitric acid and $5 \mathrm{~mL}$ of $30 \% \mathrm{H}_{2} \mathrm{O}_{2}$. Samples were analysed by flame atomic absorption spectrometry (210 VGP Atomic Absorption Spectrophotometer) in order to determine the following heavy metals: $\mathrm{Pb}$, $\mathrm{Cd}, \mathrm{Cu}$, and $\mathrm{Zn}$. The analyses were conducted in the laboratory of the Veterinarian Sanitary Direction (VSD), Bacău, Romania. 


\subsection{Quality assurance and control}

The analytical data quality was guaranteed through the implementation of laboratory quality assurance and quality control methods. The precision and accuracy of the analyses were tested by recovery measurements on spiked sediment samples. The sediment samples collected as uncontaminated sediment samples were spiked with heavy metals and digested with the same procedure as the samples. The precision of the analytical procedures, expressed as the relative standard deviation (RSD), ranged from 2 to $8 \%$. The precision for the analysis of standard solution was better than $4 \%$. The 210 VGP Atomic Absorption Spectrophotometer was first calibrated using buck certified atomic absorption standards for the respective four heavy metals in order to obtain calibration curves. Reagent blanks were first run at intervals of every sample analysis to eliminate equipment drift. All samples were carried out in triplicates for accuracy, reproducibility and precision, and the results were expressed as the mean. Average standard deviation was in the range of 0.07 and 0.19 .

The purpose of this study was the determination of heavy metals concentration in water, sediment and fish catches and if there exist the risk of poisoning the environment, ichtyofauna and human population. For the realization of this study, 39 collection stations were selected, aiming at the 5 lakes from the perimeter of the site. The areas known as being polluted (intentionally or by accident), according to the environmental reports issued by RAEP - Bacau, and the areas with an ichthyologic importance were given priority. On each accumulation basin, there have been selected 3 stations, one at the river mouth, one in the middle of the lake and one at the dam. The collection points were numbered from 1 to 39 starting with the Northern border of the site and (Lilieci Lake) and finishing in the dam area of Beresti Lake.

The employed methodology in accordance with European rules (European Union Law, Euro-pean Environment Agency) was the following: from each collection points analyses of the water, sed-iment and tissue samples were made. In the 39 collection point fishes belonging to 15 species were captured. From the tissues sampled from the collected fishes analyses regarding the concentration of heavy metals in the gills, muscles and bones were performed. European standards and values for max-imum permissible concentrations of elements in the category of surface water, streams in natural circumstances or arrangements (lakes and accumulation) are presented in Table 2 and Table 3 [23, 24].

Table 2. Permissible limits of heavy metals for water surface; WHO (World Health Organization); USEPA (United States Environmental Protection Agency)

\begin{tabular}{|c|c|c|c|}
\hline \multirow{2}{*}{ Heavy metal } & \multirow{2}{*}{ UNIT } & \multicolumn{2}{|c|}{ Permissible limit } \\
\cline { 3 - 4 } & & WHO & USEPA \\
\hline Cadmium $\left(\mathrm{Cd}^{2+}\right)$ & $\mathrm{mg} / \mathrm{L}$ & 0.005 & 0.005 \\
\hline Copper $\left(\mathrm{Cu}^{2+}\right)$ & $\mathrm{mg} / \mathrm{L}$ & 1.0 & 1.3 \\
\hline Lead $\left(\mathrm{Pb}^{2+}\right)$ & $\mathrm{mg} / \mathrm{L}$ & 0.005 & - \\
\hline Zinc $\left(\mathrm{Zn}^{2+}\right)$ & $\mathrm{mg} / \mathrm{L}$ & 5 & - \\
\hline
\end{tabular}

Table 3. Permissible limits of heavy metals for sediment by EU (European Union)

\begin{tabular}{|c|c|c|c|}
\hline $\begin{array}{c}\text { Specific chemical } \\
\text { indicators }\end{array}$ & \multirow{2}{*}{ UNIT } & \multicolumn{2}{|c|}{ Values admitted by EU } \\
\cline { 3 - 4 } & & Normal values & Alert threshold \\
\hline Cadmium $\left(\mathrm{Cd}^{2+}\right)$ & $\mathrm{mg} / \mathrm{Kg}$ & 1 & 3.5 \\
\hline Copper $\left(\mathrm{Cu}^{2+}\right)$ & $\mathrm{mg} / \mathrm{Kg}$ & 20 & 200 \\
\hline $\mathrm{Lead}\left(\mathrm{Pb}^{2+}\right)$ & $\mathrm{mg} / \mathrm{Kg}$ & 20 & 90 \\
\hline Zinc $\left(\mathrm{Zn}^{2+}\right)$ & $\mathrm{mg} / \mathrm{Kg}$ & 100 & 300 \\
\hline
\end{tabular}


Table 4. Maximum permissible level of heavy metals in fish according to international standards EU, EC

(Commission regulation) and WHO.

\begin{tabular}{|c|c|c|c|c|}
\hline \multirow{2}{*}{ Organisation } & Cadmium & Copper & Lead & Zinc \\
\cline { 2 - 5 } & \multicolumn{4}{|c|}{$\mathrm{mg} / \mathrm{Kg}$} \\
\hline WHO 1989[25] & 1.00 & 30 & 2.00 & 100 \\
\hline FAO/WHO, 2018 [26] & - & - & 0.30 & - \\
\hline EU [27] & 0.05 & 5 & 0.3 & 50 \\
\hline EC, 2005, 2008[28] & 0.05 & - & 0.20 & - \\
\hline
\end{tabular}

\subsection{The harmful effects of heavy metals on organisms}

Regarding their presence in biological systems, heavy metals are classified as essential for living organisms $(\mathrm{Cu}$, and $\mathrm{Zn})$ and nonessential $(\mathrm{Cd}$, and $\mathrm{Pb})[29]$.

Cadmium - the main sources are cigarette smoke and various foods [30]. Inhalation of cadmi-um smoke can cause unwanted lung effects and a prolonged exposure to this element may result in kidney dysfunction[30, 31]. Another damaging effect of cadmium is its interaction with other elements in the human body. An increase in the amount of $\mathrm{Cd}$ in the body is correlated with exaggerated excre-tion of calcium through the urine, which leads to demineralisation of the bones [32]. Regarding the reproductive system, cadmium affects the production of progesterone and testosterone[33] and some studies correlate the presence of $\mathrm{Cd}$ in high concentrations in the body with the incidence of prostate cancer and testicular necrosis in laboratory mice and renal and breast cancer in humans[32]. Provisional tolerable monthly intake of cadmium by WHO are $25 \mu \mathrm{g} / \mathrm{Kg}$ body weights.

Lead - is a metal found abundantly in the crust of the Earth, but is not an essential element for humans and plants [34]. Pb poisoning can cause encephalopathy and a prolonged exposure can cause a decrease in intellectual capacity and a memory impairment [30]. Lead can affect the cardiovascular system and bone metabolism, prolonged exposure to this element leading to changes in arterial pressure and inhibition of osteocalcin, a protein with a functional role in bone tissue[35, 36]. Impaired neurobe-havioral development was considered to be the most critical effect. (Food Additives Series 44, 2000 with reference to Environmental health criteria for inorganic lead, International Programme on Chemi-cal Safety (IPCS), 1995). The mean dietary exposure estimates by WHO for adults from 0.02 to $3 \mu \mathrm{g} / \mathrm{Kg}$ bw per day.

Copper - is abundant in living tissues, where as metalloprotein or other organic compounds, plays an important role in the metabolic reactions of the body [37]. Copper poisoning is rare and is mainly caused by ingestion of food and contaminated water. Symptoms are epigastric pain, nausea, vomiting and diarrhea. As far as animal organisms are concerned, copper is easily accumulated in living tissues, which must be taken into account in the management of polluted natural areas [38]. Sensitivity to the toxic effects of excess dietary copper is influenced by its chemical form, species, and interaction with other dietary minerals. WHO (1974) concluded that the fatal oral human dose is about $200 \mathrm{mg} / \mathrm{Kg}$.

Zinc - is found in various deposits in the crust of the Earth. Zinc influences the action of other metals in the body, an excess of zinc producing an excessive excretion of copper through faeces[39]. In contrast, $\mathrm{Zn}$ deficiency can lead to various immune diseases [40], which is known as an important ion in the body, acting as a signal in various cells and tissues [41]. In plants, although it is a necessary element for their development, $\mathrm{Zn}$ excess can inhibit the normal growth of roots, retards the reproductive phase of susceptible plants and affects cell organelles and membranes [42]. The average daily intake of zinc has been estimated by WHO to be maximally $20 \mathrm{mg} /$ day for adults.

\section{Results and discussions}

The analytical investigation of the heavy metals from the water, sediment and tissues of the fish covered the surface of the water over 5,500 hectares and comprised a natural protected area from the region of Moldavia (Romania) and led to the conclusion that in this site the concentrations of heavy 
metals determined in the water, sediments and fish tissues are high. In order to understand the accumulation of heavy metals in fish muscles and gills, heavy metals (i.e., $\mathrm{Cd}, \mathrm{Cu}, \mathrm{Zn}$ and $\mathrm{Pb}$ ) concentrations in the collected 15 species of fish samples were analyzed by wet digestion-based atomic adsorption technique. The collection of the samples was done constantly from the same 39 points established in the preliminary stage, presented in Table 1.

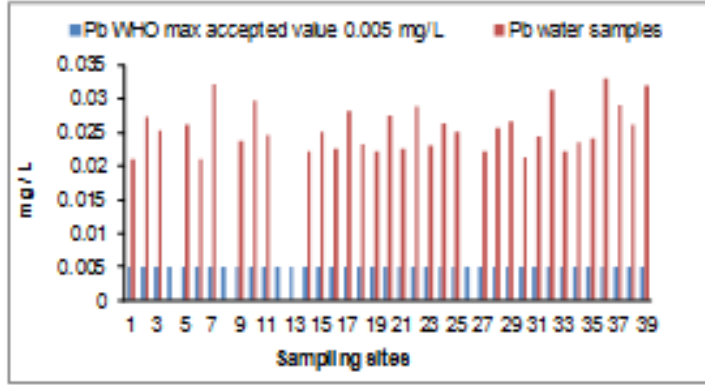

a)

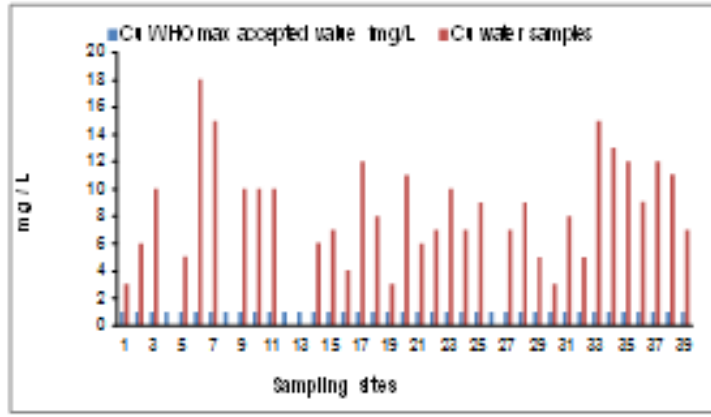

c)

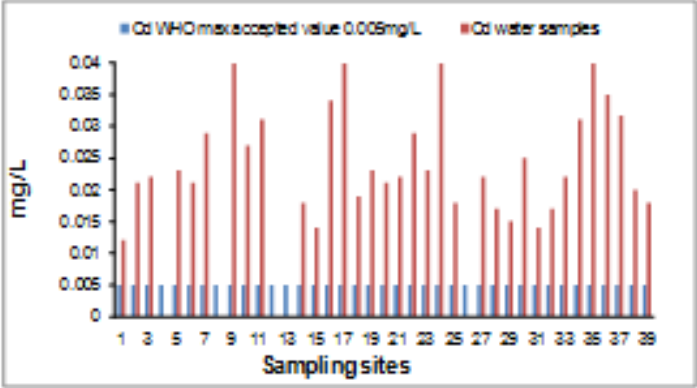

b)

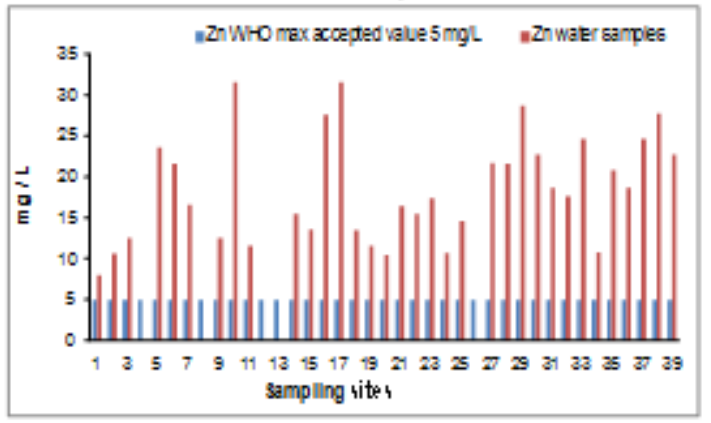

d)

Figure 2 a,b,c,d. Comparison between the maximum accepted values of heavy metals by WHO and the values found in the water tested samples from the study area

In Figure 2 represent a comparison between the maximum accepted values of heavy $(\mathrm{Pb}, \mathrm{Cd}, \mathrm{Cu}$, and $\mathrm{Zn}$ ) resulted from the analysis of the collected water samples. Can easily be observed that: the maximum allowance approved by World Health Organization (WHO) for $\mathrm{Pb}, \mathrm{Cd}, \mathrm{Cu}$ and $\mathrm{Zn}$ (presented in Table 2) is exceeded in all the points in which the collection was made. The highest concentration of Lead found in water samples was $0.0331 \mathrm{mg} / \mathrm{L}$, thus exceeding 6.62 times the maximum value allowed by the WHO. The value of the highest concentration of Cadmium found in water samples was $0.0521 \mathrm{mg} / \mathrm{L}$, thus exceeding 10.42 times the maximum value allowed by the WHO. The value of the highest concentration of copper found in water samples was $18.0430 \mathrm{mg} / \mathrm{L}$, thus exceeding 18.04 times the maximum value allowed by the WHO and the zinc concentration was 31.5370 exceeding this 6,307 times the maximum value allowed by the WHO.

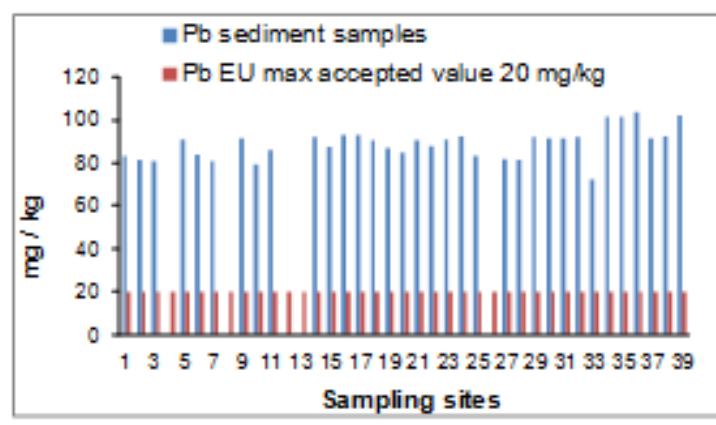

a)

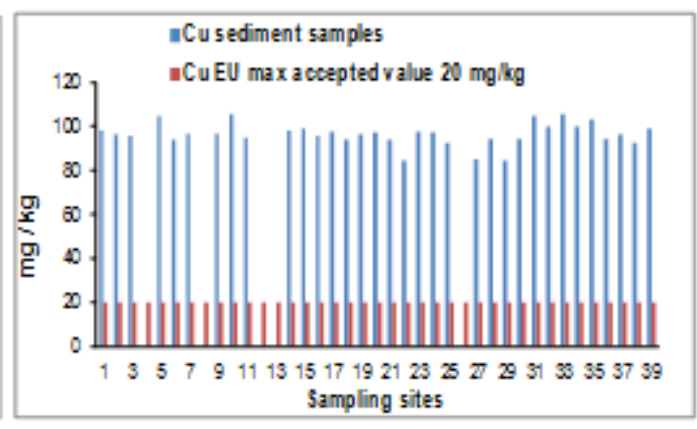

b) 


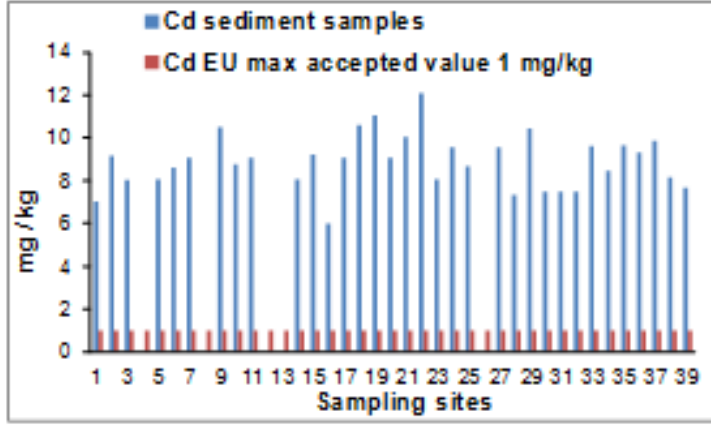

c)

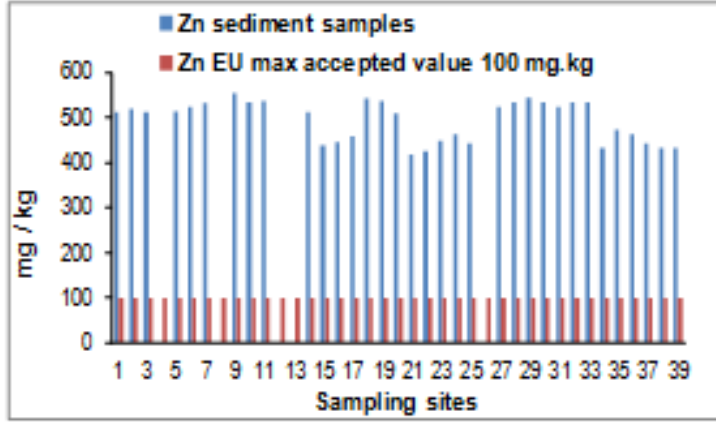

d)

Figure 3 a,b,c,d. Comparison between the maximum accepted values of heavy metals by EU and the values found in the sediment tested samples from the study area

In Figure 3 it is presented the results of the analyses of heavy metal concentration sampled from the 39 collection points at the level of the sediments. As expected, following the water analysis, the sediment samples also exceeded the maximum concentrations allowed by the EU (presented in Table 3), as follows: Lead $103.74 \mathrm{mg} / \mathrm{Kg}$, Cadmium $12.09 \mathrm{mg} / \mathrm{Kg}$, Zinc $553.74 \mathrm{mg} / \mathrm{Kg}$ these three heavy metals falling within the alert area according to Table 3, only the maximum concentration of copper found is not an alert value $(105.63 \mathrm{mg} / \mathrm{Kg})$.

The fish species captured in the 39 points are presented in Table 4. From among the individuals captured there were performed analyses for the evaluation of the quantity of heavy metals using tissue from the gills and muscles. The work was performed on medium samples collected from all the captured specimens.

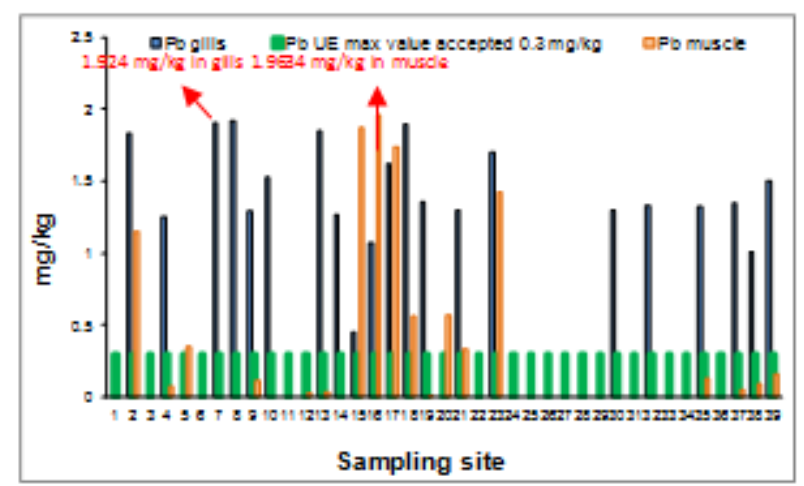

a)

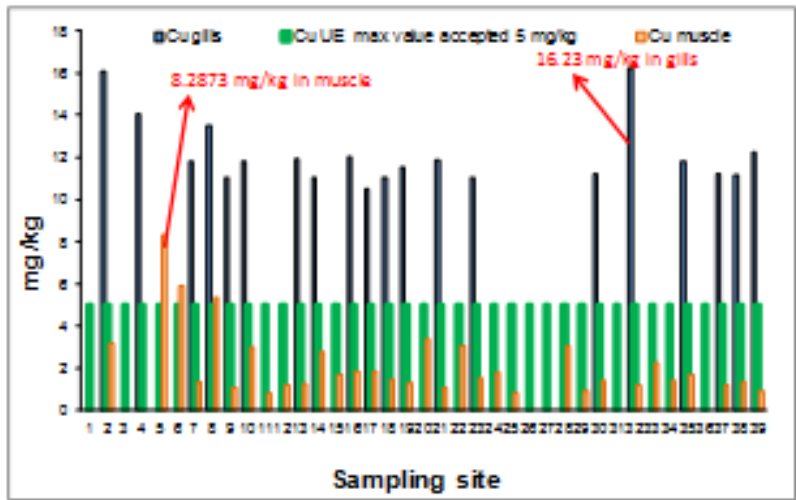

b)

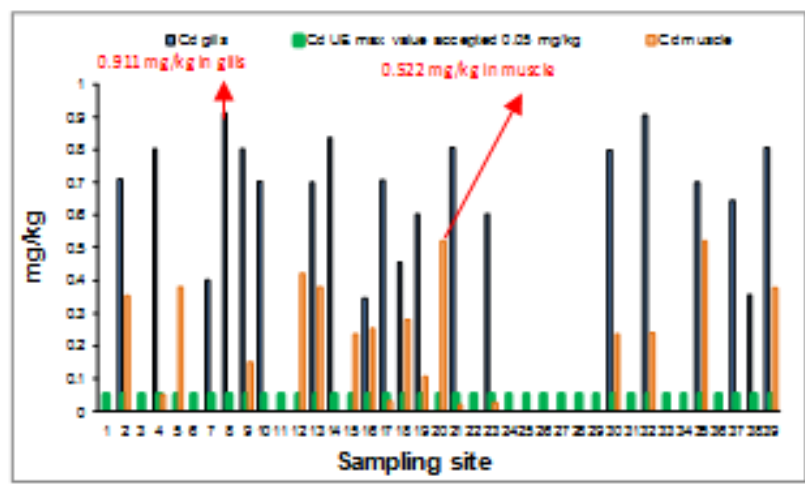

b)

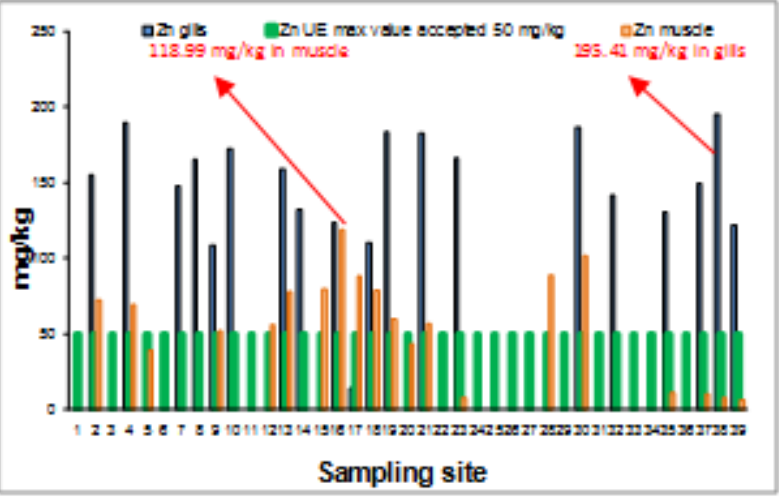

d)

Figure 4 a, b, c, d. Heavy metals value concentrations in muscle and gills tissue, sampled from the fish collected from the study area 
For the sampled fishes there were performed analyses of the heavy metals values $(\mathrm{Pb}, \mathrm{Cd}, \mathrm{Cu}$, and $\mathrm{Zn}$ ) from the gills and from the muscles. The results are presented graphically in Figure $4 \mathrm{a}, \mathrm{b}, \mathrm{c}, \mathrm{d}$ being highlighted the content of all four metals from the gills and muscles of the captured fishes in comparison with the maxim accepted concentration. The maxim concentration of $\mathrm{Pb}$ in gills was 1.924 $\mathrm{mg} / \mathrm{Kg}$ and in muscle $1.9634 \mathrm{mg} / \mathrm{Kg}$; for Cd in gills was $0.911 \mathrm{mg} / \mathrm{Kg}$ and in muscle $0.522 \mathrm{mg} / \mathrm{Kg}$; for $\mathrm{Cu}$ in gills was $16.23 \mathrm{mg} / \mathrm{Kg}$ and in muscle $8.2873 \mathrm{mg} / \mathrm{Kg}$; while for $\mathrm{Zn}$ in gills was $195.41 \mathrm{mg} / \mathrm{Kg}$ and in muscle $118.99 \mathrm{mg} / \mathrm{Kg}$. Can be observed that in most of the cases the maxim accepted concentrations in UE of all four metals $(\mathrm{Pb}=0.3 \mathrm{mg} / \mathrm{Kg} ; \mathrm{Cd}=0.05 \mathrm{mg} / \mathrm{Kg} ; \mathrm{Cu}=5 \mathrm{mg} / \mathrm{Kg} ; \mathrm{Zn}=50$ $\mathrm{mg} / \mathrm{Kg}$ ) are exceed-ed. Figure 4 are highlighted with a red bolded line the maximum values of the $\mathrm{Pb}$, $\mathrm{Cd}, \mathrm{Cu}$ and $\mathrm{Zn}$ found in fish samples both in gills and muscles, respectively.

This study, revealed through the paired student t-test that the studied heavy metals concentra-tions in fifteen species of fishes, fished from the Buhusi-Bacau-Beresti Storage basin, in muscles was significant different than that of the gills at a $98 \%$ confidence level. All samples from the fish captured in weekend were analyzed the following week Monday, refrigerated at $4^{\circ} \mathrm{C}$. Therefore, it has been suggested that meat variation has an significant impact on changes of heavy metal level in the studied fish samples of "Beresti-Bacau-Buhusi" Storage basin, Romania. From Table 5, can easy be observed that the heavy metals concentrations in muscles for most of the fishes captured in rainy season is lower than that of the fishes captured in non rainy season, which was in good agreement with literature [43, 44].

Table 5. Heavy metals concentrations $(\mathrm{mg} / \mathrm{Kg})$ in muscle samples of fish caught in different seasons

\begin{tabular}{|c|c|c|c|c|c|}
\hline Type of season & Pb & $\mathbf{C d}$ & $\mathbf{C u}$ & $\mathbf{Z n}$ & Reference \\
\hline \multirow{3}{*}{ Rainy season } & $8.84 \pm 6.35$ & $2.68 \pm 3.03$ & $5.24 \pm 0.08$ & $13.51 \pm 5.15$ & {$[43]$} \\
\cline { 2 - 6 } & $\mathrm{BDL}$ & $\mathrm{BDL}$ & $\mathrm{BDL}$ & $30.84 \pm 1.24$ & {$[44]$} \\
\cline { 2 - 6 } & 0.0238 & 0.0197 & 0.7903 & 5.7962 & This study \\
\hline \multirow{2}{*}{ Non rainy season } & $12.57 \pm 2.25$ & $0.60 \pm 0.81$ & $5.34 \pm 0.03$ & $69.80 \pm 41.33$ & {$[43]$} \\
\cline { 2 - 6 } & $\mathrm{BDL}$ & $\mathrm{BDL}$ & $0.95 \pm 0.02$ & $74.11 \pm 1.33$ & {$[44]$} \\
\cline { 2 - 6 } & 1.9634 & 0.522 & 8.2873 & 118.99 & This study \\
\hline
\end{tabular}

Maximum value of: $\mathrm{Pb}$ are found in gills samples from the collection points: $\mathrm{P} 7(1.9054 \mathrm{mg} / \mathrm{Kg})$, P8 (1.9240 mg/Kg), P13 (1.8475 mg/Kg) and P18 $(1.8955 \mathrm{mg} / \mathrm{Kg})$ and from the muscle sam-ples: P15 $(1.8766 \mathrm{mg} / \mathrm{Kg}), \mathrm{P} 16(1.9634 \mathrm{mg} / \mathrm{Kg}), \mathrm{P} 17(1.7387 \mathrm{mg} / \mathrm{Kg})$ and P23 $(1.4253 \mathrm{mg} / \mathrm{Kg})$ being registered constant exceeding of the maximally accepted norms; for $\mathrm{Cd}$ the maximum values in gills were found in the collection points: P8 $(0.911 \mathrm{mg} / \mathrm{Kg}), \mathrm{P} 14(0.8349 \mathrm{mg} / \mathrm{Kg}), \mathrm{P} 32(0.9065 \mathrm{mg} / \mathrm{Kg})$ and P39 $(0.8051$ $\mathrm{mg} / \mathrm{Kg})$ and from the muscle samples: P5 $(0.3804 \mathrm{mg} / \mathrm{Kg}), \mathrm{P} 12(0.42 \mathrm{mg} / \mathrm{Kg}), \mathrm{P} 20(0.522 \mathrm{mg} / \mathrm{Kg})$ and P35 $(0.52 \mathrm{mg} / \mathrm{Kg})$; for $\mathrm{Cu}$ the maximum values in gills were found in the collection points: P2 $(16.1024 \mathrm{mg} / \mathrm{Kg}), \mathrm{P} 4(14.0694 \mathrm{mg} / \mathrm{Kg}), \mathrm{P} 32(16.23 \mathrm{mg} / \mathrm{Kg})$ and P39 $(12.2462 \mathrm{mg} / \mathrm{Kg})$ and from the muscle samples: P5 (8.2873 mg/Kg), P6 (5.9091 mg/Kg), P8 (5.327 mg/Kg) and P20 (3.3806 mg/Kg); for $\mathrm{Zn}$ the maximum values in gills were found in the collection points: P4 (189.4263 mg/Kg), P19 (183.3675 $\mathrm{mg} / \mathrm{Kg})$, P30 (186.6875) and P38 (195.4167 mg/Kg) and from the muscle samples: P16 (118.99 mg/Kg), P17 (88.3 mg/Kg), P28 (88.55 mg/Kg) and P30 (101.34 mg/Kg).

The results of the fish captures are presented in Table 6 where there are indicated the number of the sampling site and the species of the captured fishes from that area. Analyzing the results ob-tained from both muscle and gill samples, can conclude that heavy metals are accumulated more in gills than muscles. 
Table 6. Fish species collected from the 39 sampling sites

\begin{tabular}{|c|c|c|c|}
\hline No. & $\begin{array}{l}\text { Sampling } \\
\text { site }\end{array}$ & Description & Collected fish species \\
\hline 1. & P1 & Lilieci reservoir & European perch-Perca finviatilis; \\
\hline 2. & P2 & Lilieci reservoir & Common bleak - Alburnus alburmus; \\
\hline 3. & P 3 & Lilieci reservoir & European perch-Perca fluviatilis; \\
\hline 4. & P4 & Lilieci reservoir & Common roach - Rutilus rutilus; Prussian carp - Carassius gibelio; \\
\hline 5. & P 5 & Bistrița river & $\begin{array}{c}\text { Europeanperch - Perca fluviatilis; Prussian carp - Carassius gibelio; Ruffe - } \\
\text { Gymnocephalus cernuus gobio obtusirostris; }\end{array}$ \\
\hline 6. & P 6 & Bistrita river & Common bleak - Alburnus alburnus; \\
\hline 7. & P7 & Bacău reservoir & Common roach - Rutilus rutilus; Northern pike - Esox lucius; \\
\hline 8. & P 8 & Bacău reservoir & $\begin{array}{c}\text { European perch - Perca fluviatilis; Northem pike - Esox lucius; Schneider - } \\
\text { Alburnoides bipunctatus; Common roach - Rutilus rutilus; }\end{array}$ \\
\hline 9. & P9 & Bacău reservoir & Common bream - Abramis brama; Common rudd - Scardinius erythrophthaimus; \\
\hline 10. & P 10 & Bacău reservoir & European perch - Perca fluviatilis; Northem pike - Esox lucius; \\
\hline 11. & P 11 & Bacău reservoir & $\begin{array}{c}\text { European perch - Perca fliviatilis; Common roach - Rutilus rutilus; Common bleak } \\
- \text { Alburnus alburnus; }\end{array}$ \\
\hline 12. & P12 & Bacău reservoir & Northem pike - Esox lucius; \\
\hline 13. & P 13 & Bacău reservoir & $\begin{array}{l}\text { European perch - Perca fluviatilis; Northem pike - Esox lucius; Common roach- } \\
\text { Rutilus rutilus; }\end{array}$ \\
\hline 14. & P 14 & $\begin{array}{l}\text { Confluence of Bistritta } \\
\text { and Siret rivers }\end{array}$ & $\begin{array}{c}\text { European perch - Perca fluviatilis; European chub - Squalius cephalus; Northem } \\
\text { pike - Esox lucius; Common roach - Rutilus rutilus; }\end{array}$ \\
\hline 15. & P 15 & $\begin{array}{l}\text { Confluence of Bistritia } \\
\text { and Siret rivers }\end{array}$ & European perch - Perca fluviatilis; Prussian carp - Carassius gibelio; \\
\hline 16. & P 16 & $\begin{array}{l}\text { Confluence of Bistrița } \\
\text { and Siret rivers }\end{array}$ & Prussian carp - Carassius gibelio; Common bream - Abramis brama; \\
\hline 17. & P 17 & $\begin{array}{l}\text { Confluence of Bistritta } \\
\text { and Siret rivers }\end{array}$ & Vimba bream - Vimba vimba; Common bream - Abramis brama; \\
\hline 18. & P 18 & $\begin{array}{l}\text { Confluence of Bistritia } \\
\text { and Siret rivers }\end{array}$ & Prussian carp - Carassius gibelio; \\
\hline 19. & P 19 & Galbeni reservoir & $\begin{array}{c}\text { Prussian carp - Carassius gibelio; Northern pike - Esox lucius; European perch - } \\
\text { Perca fluviatilis; }\end{array}$ \\
\hline 20. & P 20 & Galbeni reservoir & $\begin{array}{l}\text { Common roach - Rutilus rutilus; Northempike - Esox lucius; } \\
\text { Prussian carp - Carassius gibelio; Zander - Sander lucioperca; }\end{array}$ \\
\hline 21. & P 21 & Galbeni reservoir & $\begin{array}{c}\text { Common bream - Abramis brama; Prussian carp - Carassius gibelio; } \\
\text { Northempike - Esox lucius; Prussian carp - Carassius gibelio; Common roach - } \\
\text { Rutilius rutilus; }\end{array}$ \\
\hline 22. & P 22 & Galbeni reservoir & Prussian carp - Carassius gibelio; \\
\hline 23. & P 23 & Galbeni reservoir & $\begin{array}{c}\text { Prussian carp - Carassius gibelio; Common bream - Abramis brama; } \\
\text { Europeanperch - Perca fluviatilis; }\end{array}$ \\
\hline 24. & P 24 & Siret river & $\begin{array}{c}\text { Spirlin - Alburnoides bipunctatus; Prussian carp - Carassius gibelio; European chub } \\
\text { - Squalius cephalus; Ruffe - Gymnocephalus cernuus; }\end{array}$ \\
\hline 25. & P 25 & Siret river & Europeanperch - Perca fluviatilis; Prussian carp - Carassius gibelio; \\
\hline 26. & P26 & Siret river & Zander - Sander lucioperca \\
\hline 27. & P 27 & Răcăciuni reservoir & $\begin{array}{l}\text { Zander - Sander lucioperca; Prussian carp - Carassius gibelio; Zarte - Vimba } \\
\text { vimba; }\end{array}$ \\
\hline 28. & P 28 & Răcăciuni reservoir & Europeanperch - Perca fluviatilis; Common bleak - Alburnus alburnus; \\
\hline 29. & P29 & Răcăciuni reservoir & Commoncarp-Cyprinus carpio; \\
\hline 30. & P 30 & Răcăciuni reservoir & $\begin{array}{c}\text { Prussian carp - Carassius gibelio; Zander - Sander lucioperca; } \\
\text { Welscatfish - Silurus glanis; }\end{array}$ \\
\hline 31. & P31 & Siret river & Prussian carp-Carassius gibelio; \\
\hline 32. & P 32 & Siret river & EuropeanPerch - Perca finviatilis; \\
\hline 33. & P33 & Berești reservoir & Europeanperch - Perca fluviatilis; Northempike - Esox lucius; \\
\hline 34. & P 34 & Berești reservoir & $\begin{array}{l}\text { Common rudd - Scardinius erythrophthalmus; Europeanperch - Perca fivviatilis; } \\
\text { Northernpike - Esox lucius; }\end{array}$ \\
\hline 35. & P 35 & Berești reservoir & Europeanperch - Perca fluviatilis; Zander - Sander lucioperca; \\
\hline 36. & P 36 & Berești reservoir & $\begin{array}{c}\text { Vimba bream - Vimba vimba; Common bream - Abramis brama; } \\
\text { Europeanperch - Perca fluviatilis; }\end{array}$ \\
\hline 37. & P 37 & Berești reservoir & $\begin{aligned} \text { Common roach - Rutilus rutilius; Prussian carp - Carassius gibelio; European perch } \\
\text { - Perca fluviatilis; Northernpike - Esox lucius; }\end{aligned}$ \\
\hline 38. & P 38 & Berești reservoir & $\begin{array}{c}\text { Common bream - Abramis brama; Prussian carp - Carassius gibelio; Vimba bream } \\
\text {-Vimba vimba; Common roach - Rutilus rutilus; }\end{array}$ \\
\hline 39. & P 39 & Berești reservoir & Common bream - Abramis brama; \\
\hline
\end{tabular}

This study revealed that the maximum Cd concentration $(0.911 \mathrm{mg} / \mathrm{Kg})$ was found in fish gills of specie European Perch - Perca fluviatilis and the minimum $(0.0197 \mathrm{mg} / \mathrm{Kg})$ was found in Zander Sander lucioperca fish muscle sample. Subsequently, high Cd concentrations found in Common bleak 
- Alburnus Alburnus, Zarte - Vimba Vimba and Ruffe - Gymnocephalus Cernuus, were found as $0.8349 \mathrm{mg} / \mathrm{Kg}, 0.9065 \mathrm{mg} / \mathrm{Kg}$ and $0.8051 \mathrm{mg} / \mathrm{Kg}$ respectively. Zn levels in fish gills of the studied samples were ranged from $108.6698 \mathrm{mg} / \mathrm{Kg}$ to $195.4167 \mathrm{mg} / \mathrm{Kg}$. The varia-tion of $\mathrm{Zn}$ concentration in fifteen species of fishes was statistically significant in gills and muscle. However, zinc levels in this study were not like in the literature, which reported ranges from 2.74 to $11.57 \mathrm{mg} / \mathrm{Kg}$ in fish from the Yangtze River [45], 4.327 to $5.668 \mathrm{mg} / \mathrm{Kg}$ in fish collected from the Yellow River [46] and 2.7 to 9.3 $\mathrm{mg} / \mathrm{Kg}$ in fish from Rio de Janeiro State [47]. Higher Zn levels approaching to our results were obtained for fish collected from the Black and Aegean Seas by Uluozlu et. al [48] with Zn concentrations ranging from 35.4 to $106 \mathrm{mg} / \mathrm{Kg}$ in fish flash. The maximum $\mathrm{Pb}$ concentration in gills $(1.924 \mathrm{mg} / \mathrm{Kg})$ was found in the fish sample of Zarte - Vimba Vimba, while the minimum concen-tration $(0.45$ $\mathrm{mg} / \mathrm{Kg}$ ) was found in European Perch - Perca fluviatilis. Pb concentrations were also found: 1.905, 1.8475 and $1.8955 \mathrm{mg} / \mathrm{Kg}$ in the fish species of Common bleak - Alburnus Alburnus, in Northernpike Esox Lucius, and respectively Prussian carp - Carassius Gibelio. The heavy metal found in the samples analyzed in the largest quantity is copper, with a value of $(16.23 \mathrm{mg} / \mathrm{Kg})$ in the gills of Northernpike Esox Lucius fish.

\section{Conclusions}

Heavy metals are found in conjunction, as demonstrated by the analyses we performed and rendered synthetically in Figures 2-4, which leads to an increased level of danger for the ecosystem and for the people, a larger degree of contamination being registered because of the synergic development of toxicity and because fishes are organisms in which pollutants are accumulated. The maximum allowance in water samples approved by World Health Organization (WHO) for $\mathrm{Pb}, \mathrm{Cd}, \mathrm{Cu}$ and $\mathrm{Zn}$ (presented in Table 2) is exceeded in all the points in which the collection was made: Lead $(0.0331 \mathrm{mg}$ / L), exceeding 6.62 times the maximum value; Cadmium $(0.0521 \mathrm{mg} / \mathrm{L})$, exceeding 10.42 times the maximum value; Copper (18.0430 mg / L), exceeding 18.04 times the maximum value and Zinc $(31.5370 \mathrm{mg} / \mathrm{L})$ exceeding 6,307 times the maximum value allowed. The sediment samples also exceeded the maximum concentrations allowed by the EU, as follows: Lead $103.74 \mathrm{mg} / \mathrm{Kg}$, Cadmium $12.09 \mathrm{mg} / \mathrm{Kg}$ and Zinc $553.74 \mathrm{mg} / \mathrm{Kg}$, these three heavy metals falling within the alert area according to Table 3, only the maximum concentration of copper found is not an alert value $(105.63 \mathrm{mg} / \mathrm{Kg})$.

The maxim concentration of $\mathrm{Pb}$ in gills was $1.924 \mathrm{mg} / \mathrm{Kg}$ and in muscle $1.9634 \mathrm{mg} / \mathrm{Kg}$; for Cd in gills was $0.911 \mathrm{mg} / \mathrm{Kg}$ and in muscle $0.522 \mathrm{mg} / \mathrm{Kg}$; for $\mathrm{Cu}$ in gills was $16.23 \mathrm{mg} / \mathrm{Kg}$ and in muscle $8.2873 \mathrm{mg} / \mathrm{Kg}$; while for $\mathrm{Zn}$ in gills was $195.41 \mathrm{mg} / \mathrm{Kg}$ and in muscle $118.99 \mathrm{mg} / \mathrm{Kg}$. Can be observed that in most of the cases the maxim accepted concentrations in $\mathrm{EU}$ of all four metals $(\mathrm{Pb}=0.3 \mathrm{mg} / \mathrm{Kg}$; $\mathrm{Cd}=0.05 \mathrm{mg} / \mathrm{Kg} ; \mathrm{Cu}=5 \mathrm{mg} / \mathrm{Kg} ; \mathrm{Zn}=50 \mathrm{mg} / \mathrm{Kg}$ ) are exceeded. The heavy metal found in the samples analyzed in the largest quantity is copper, with a value of $(16.23 \mathrm{mg} / \mathrm{Kg})$ in the gills of Northernpike Esox Lucius fish. Can easily be observed that there is not a linear dependency between the quantities of heavy metals determined in the water, sediments and fish tissues. From the analyses of the tissues, can be observed that gills are more sensitive and they register a higher bioaccumulation. Fortunately, the gills are not usually consumed by humans, this part being removed during the evisceration of the fish. This study revealed that the concentrations of heavy metals in all fifteen species analyzed in the study area were not generally safe for consumption when fish are consumed with gills.

The main conclusion that can be drawn from this study is that anthropic activities performed in the area have left their negative mark on the fish populations from the studied site. The harmfulness of the pollution of the water, sediment and fish is indirectly reverberated upon humans.

Recommendations that would lead to the avoidance of an ecological disaster with serious repercussions upon the population from the area:

-the complete cessation of emission of all classes of toxic substance through the interdiction of their manufacturing in conditions that do not ensure the protection of the environment;

-the evaluation of the export of metals towards the studied area by means of the underground water; 
-the characterization of the distribution of heavy metals on the entire trophic chain up to the man;

-the identification of the manners in which one can make the distinction between bacKground concentrations and the one caused by man's actions;

-the improvement the economic evaluation procedures in such a way that take into account the negative effects of the retention services of pollutants in aquatic systems;

-the maintenance of the emissions of other classes of substances beneath a certain level;

-the evaluation and attenuation of the toxic substances which are emitted accidentally;

-development and introduction of a series of procedures directed at stopping heavy metals pollution and protecting the environment.

Acknowledgements: This study was accomplished by the help of RAEP (Regional Agency for Environmental Protection) Bacău, VSD (Veterinarian Sanitary Direction) and funded by CRE (Environmental Regional Centre NGO) Bacău, Romania.

\section{References}

1.STEFAN, D.S., Assessment of Heavy Metals Pollution of Snagov Lake, Romania. Rev. Chim., 68(2), 2017, 215-220.

2.WATSON, R., et al., Mapping global fisheries: sharpening our focus. Fish and fisheries, 2004. 5(2): p. $168-177$.

3.IONESCU, P., Assessment of Heavy Metals Levels in Water, Sediments and Fish from Plumbuita Lake, Romania, Rev. Chim., 67(11), 2016

4.RESETAR-DEAC, A.-M., DIACU, E., Assessment of Aquatic Environment Contamination with Heavy Metals from Abandoned Mines of Northwestern Romania, Rev. Chim., 66(9), 2015, 135.

5.***Standard methods for the examination of water \& wastewater Volume 1. 2005, Washingtong, DC: American Public Health Association.

6.MILAČIČ, R., et al., Potentially toxic elements in water, sediments and fish of the Evrotas River under variable water discharges. Science of The Total Environment, 2019. 648: p. 1087-1096.

7.L.TEODOROF, Bioaccumulation of Heavy Metals in Fish from Dobrudja Aquaculture Farm. 2009: Rev. Chim., 60(11), 2009

8.CASHION, T., et al., Review and advancement of the marine biotic resource use metric in seafood LCAs: a case study of Norwegian salmon feed. The International Journal of Life Cycle Assessment, 2016. 21(8): p. 1106-1120.

9.ANANDHAN, R., et al., Effect of aluminium on development of Zebrafish, Brachydanio rerio (Ham.). International Journal of Pharmacy \& Life Sciences, 2013. 4(4).

10.BHUYAN, M.S., et al., Heavy metal contamination in surface water and sediment of the Meghna River, Bangladesh. Environmental nanotechnology, monitoring \& management, 2017. 8: p. 273-279.

11.AUTHMAN, M.M., W.T. ABBAS, A.Y. GAAFAR, Metals concentrations in Nile tilapia Oreochromis niloticus () from illegal fish farm in Al-Minufiya Province, Egypt, and their effects on some tissues structures. Ecotoxicology and environmental safety, 2012. 84: p. 163-172.

12.PRICOPE, F., Environmental Pollution and Conservation of Nature. 2 edn. Rovimed Publishers Bacau, 2007.

13.ZHOU, Q., et al., Biomonitoring: An appealing tool for assessment of metal pollution in the aquatic ecosystem. Vol. 606. 2008. 135-50.

14.***CEE, 'Council Directive 79/409/CeeFrom 2 April 1979 on the Conservation of Wild Birds (79/409/Cee)'. 1979.

15.IONESCU, P., et al., Quality Assessment of Some Freshwater Resources Located in Bucharest and Surrounding Areas., Rev. Chim., 70(10), 2019, 3638-3643.

16.BIRDLIFE, F.V.B., Birds in Europe: population estimates, trends and conservation status. 2004: Cambridge. 
17.888FAO, 'Fisheries and Aquaculture Topics. Utilization and Trade. Topics Fact Sheets.', FAO,. 2001-2014.

18.WANG, X., et al., Health risks of heavy metals to the general public in Tianjin, China via consumption of vegetables and fish. Science of the total environment, 2005. 350(1-3): p. 28-37.

19.CHIEN, L.-C., et al., Daily intake of TBT, Cu, Zn, Cd and As for fishermen in Taiwan. Science of the total environment, 2002. 285(1-3): p. 177-185.

20. CIA, C. CIA world factbook. Washington, DC: United States Central Intelligence Agency (CIA), 2014.

21.ISLAM, M.S., M.K. AHMED, M. HABIBULLAH-AL-MAMUN, Determination of heavy metals in fish and vegetables in Bangladesh and health implications. Human and Ecological Risk Assessment: An International Journal, 2015. 21(4): p. 986-1006.

22.ISLAM, G.R., et al., Heavy metal contamination of freshwater prawn (Macrobrachium rosenbergii) and prawn feed in Bangladesh: a market-based study to highlight probable health risks. Chemosphere, 2017. 170: p. 282-289.

23.CHOI, Y., International/national standards for heavy metals in food. Government Laboratory, 2011: p. 1-13.

24.PAUL, D., Research on heavy metal pollution of river Ganga: A review. Annals of Agrarian Science, 2017. 15: p. 278-286.

25.MOKHTAR, M.B., et al., Assessment level of heavy metals in Penaeus monodon and Oreochromis spp. in selected aquaculture ponds of high densities development area. European Journal of Scientific Research, 2009. 30(3): p. 348-360.

26.***Commission, C.A., Codex Stan 193-1995 General standard for contaminants and toxins in food and feed. 2012.

27.***Commission, E., Commission Regulation (EC) No. 629/2008 of 2 July 2008 amending Regulation (EC) No. 1881/2006 setting maximum levels for certain contaminants in foodstuffs. Official Journal of the European Union L, 2008. 173: p. 6-9.

28.IONESCU, P., et al., Assessment of Potential Toxic Elements in Muscle Tissues of Different Fish Species from Colentina, Dambovita and Arges Rivers, Romania.

29.IONESCU, P., Assessment of Potential Toxic Elements in Muscle Tissue of Different Fish Species from Colentina, Dambovita and Arges Rivers, Romania. 2020: Rev. Chim., 71(3), 2020, 19-28

30.JÄRUP, L., Hazards of heavy metal contamination. British medical bulletin, 2003. 68(1): p. 167182.

31.JÄRUP, L., A. ÅKESSON, Current status of cadmium as an environmental health problem. Toxicology and applied pharmacology, 2009. 238(3): p. 201-208.

32.SATARUG, S., M.R. MOORE, Adverse health effects of chronic exposure to low-level cadmium in foodstuffs and cigarette smoke. Environmental health perspectives, 2004. 112(10): p. 1099-1103.

33.GODT, J., et al., The toxicity of cadmium and resulting hazards for human health. Journal of occupational medicine and toxicology, 2006. 1(1): p. 22.

34.WANG, J., et al., Combined effects of cadmium and salinity on juvenile Takifugu obscurus: cadmium moderates salinity tolerance; salinity decreases the toxicity of cadmium. Scientific reports, 2016. 6(1): p. 1-9.

35.GOYER, R.A., Lead toxicity: current concerns. Environmental health perspectives, 1993. 100: p. 177-187.

36.GOYER, R.A., Lead toxicity: from overt to subclinical to subtle health effects. Environmental Health Perspectives, 1990. 86: p. 177-181.

37.***Organization, W.H., Trace elements in human nutrition and health. 1996.

38.HAN, B.C., et al., Copper intake and health threat by consuming seafood from coppercontaminated coastal environments in taiwan. Environmental Toxicology and Chemistry, 1994. 13(5): p. 775-780.

39.FOSMIRE, G.J., Zinc toxicity. The American journal of clinical nutrition, 1990. 51(2): p. 225-227. 
40.PRASAD, A.S., Zinc in human health: effect of zinc on immune cells. Molecular medicine, 2008. 14(5-6): p. 353-357.

41.FREDERICKSON, C.J., J.-Y. KOH, A.I. BUSH, The neurobiology of zinc in health and disease. Nature Reviews Neuroscience, 2005. 6(6): p. 449.

42.ROUT, G.R., P. DAS, Effect of metal toxicity on plant growth and metabolism: I. Zinc, in Sustainable agriculture. 2009, Springer. p. 873-884.

43.ZINEB, D., Y. DALI, Seasonal variations of some heavy metals in common carp (Cyprinus carpio L., 1758) collected from El Izdihar Dam of Sidi Abdelli (Tlemcen) in North-Western Algeria. Annals of Biological Research, 2013. 4(1): p. 232-237.

44.SALEM, Z.B., et al., Seasonal variation of heavy metals in water, sediment and roach tissues in a landfill draining system pond (Etueffont, France). Ecological Engineering, 2014. 69: p. 25-37.

45.YI, Y., Z. YANG, S. ZHANG, Ecological risk assessment of heavy metals in sediment and human health risk assessment of heavy metals in fishes in the middle and lower reaches of the Yangtze River basin. Environmental pollution, 2011. 159(10): p. 2575-2585.

46.WANG, Y., et al., Heavy metal concentrations in water, sediment, and tissues of two fish species (Triplohysa pappenheimi, Gobio hwanghensis) from the Lanzhou section of the Yellow River, China. Environmental monitoring and assessment, 2010. 165(1-4): p. 97-102.

47.MEDEIROS, R.J., et al., Determination of inorganic trace elements in edible marine fish from Rio de Janeiro State, Brazil. Food Control, 2012. 23(2): p. 535-541.

48.ULUOZLU, O.D., et al., Trace metal content in nine species of fish from the Black and Aegean Seas, Turkey. Food chemistry, 2007. 104(2): p. 835-840.

$\overline{\text { Manuscript received: } 6.04 .2020}$ 